\title{
Changes in physico-mechanical properties of water caltrop fruit (Trapa natans $L$.) during the drying process
}

\author{
Cezary Toma' ${ }^{1} \cdot$ Mariusz Kukliński $^{2} \cdot$ Zygmunt Dajdok $^{3}(\mathbb{C}$
}

Received: 8 October 2020 / Revised: 11 October 2021 / Accepted: 12 October 2021 / Published online: 25 October 2021

(c) The Author(s) 2021

\begin{abstract}
The cosmopolitan water caltrop plant (Trapa natans L.) produces nuts, which in the maturing process develop very hard pericarps. This hardness, together with structure and shape (external spikes) of pericarp and seed, and the water contained in the fruit are responsible for their mechanical properties. This study determined the force needed to break Trapa natans nuts at various drying stages, with tests having been carried out at weekly intervals until the fruit dried completely. The amount of force necessary for cracking nuts at each of the 6 drying stages was determined, as well as the work of crushing calculated until the greatest compressive force (crushing force) was reached. The force needed to rupture the hydrated fruit in the horizontal plane was higher than that necessary for the rupture of dried fruit. The experiment showed that the maximum force needed to crush the fruit was $828.7 \mathrm{~N}$ and occurred when crushing the fruit after 2 weeks of drying, while the largest calculated crushing work was $2185.5 \mathrm{~mJ}$ for the same fruit. Other strength parameters were introduced to characterize mechanical properties of water caltrop in a more extensive scope. These are hardness defined as a ratio of compressive force increment to strain increment, specific crushing energy defined as a ratio of crushing work to water caltrop's mass, and unit crashing force defined as a ratio of crushing force to caltrop's thickness. All these parameters reached their highest mean values for pericarps after 2 weeks of desiccation. Mass measurements were also applied in modelling the desiccation process by the exponential function. The very dense pericarp material, after reaching maturity, slightly changes during drying. It can be used industrially as an extremely durable and biodegradable biological material. Results also suggest that the great evolutionary success of the species may result from the ability of the pericarp to protect its seeds, leading to the spread of this species in aquatic environments.
\end{abstract}

Keywords Fruit $\cdot$ Trapa $\cdot$ Pericarp $\cdot$ Mechanical resistance $\cdot$ Hydration

\author{
Abbreviations \\ $B \quad$ The constant parameter in the desiccation expo- \\ nential function calculated by the least square \\ method \\ CF Crushing force (N) \\ $\mathrm{CW}$ Crushing work (mJ)
}

Communicated by: Lukasz Stepien

Cezary Toma

cezarytoma@poczta.onet.pl

1 Department of Carpology, Kazimierz Wielki University, Chodkiewicza 30, 85-064 Bydgoszcz, Poland

2 Department of Mechanics and Computer Methods, University of Science and Technology, Al. prof. S. Kaliskiego 7, 85-796 Bydgoszcz, Poland

3 Department of Botany, University of Wrocław, Kanonia 6/8, 50-328 Wrocław, Poland
HRD Hardness parameter expressing the relationship between compressive loading (N) and longitudinal strain $(\mathrm{mm} / \mathrm{mm})$

IN Internal surface

LZ Initial length of water caltrop in the direction of axis $Z(\mathrm{~mm})$

$m_{t} \quad$ Mass of water caltrop after " $t$ " weeks of desiccation $(\mathrm{g})$

$m_{0} \quad$ Mass of the water caltrop right out of water $(\mathrm{g})$

OU Outer surface

SCE Specific crushing energy $(\mathrm{mJ} / \mathrm{g})$

TWS Thickness measured along the $X$ axis without spikes (mm)

UCF Unit crushing force $(\mathrm{N} / \mathrm{mm}) \mathrm{UCF}=\mathrm{CF} / \mathrm{TWS}$ 


\section{Introduction}

Trapa natans L., also known by its common name, water caltrop, is a cosmopolitan element of vascular flora (Zając and Zając 2009). The area of its natural occurrence covers Europe - from Spain in the west to Russia in the east and from the southern outskirts of the Scandinavian Peninsula in the north to the Balkan Peninsula and the Black Sea regions in the south (Hultén and Fries 1986; Piórecki 2014). Outside Europe, it occurs in Asia and Africa and as an invasive species in Australia and North America. Nowadays the Trapa genus belongs to the subfamily Trapoideae, the family Lythraceae, and the order Myrtales (Stevens 2001). The diversity of the size and shape of Trapa natans fruit has become the basis for distinguishing many taxa within the genus Trapa. Water caltrop is an annual aquatic plant rooted at the bottom of water bodies or rivers. Its shoots grow up to the water surface, on which they form leaf rosettes with flowers and fruit. The species occurs in stagnant and slow-flowing waters, mainly in oxbow lakes and fish ponds. In river beds, individuals of Trapa natans are found mainly along the banks, e.g. in bays between artificially built spurs. This species prefers eutrophic waters rich in nutrients. Trapa natans usually produces mono-seeded nuts $2-4.5 \mathrm{~cm}$ long and 1-3 cm wide. Trapa natans seeds are characterized by a high content of starch and protein. For this reason, they have long been used in Europe and Asia for human food and feed for farm animals (Piórecki 1980). The plant's fruit is also used for medicinal and cosmetic purposes, among others (Chaudhary et al. 2012). This species is also used as a bioindicator of metals in lakes (Petrović et al. 2016). The pericarp of the fruit of this species is used as an organic herbicide (Javed et al. 2016). The chemical composition and pharmacological activity of pericarps of Trapa natans have been studied, among others by Gani et al. (2010), Shalabh et al. (2012), and Bharthi et al. (2015). Additionally, studies on the physicochemical properties during Trapa natans nut storage were conducted by Singh et al. (2010). Trapa natans nuts are eaten by many animal species. The literature on Trapa natans nut consumption mainly mentions rodents, including muskrats (Ondatra zibethicus L.) (Muenscher 1937; Winne 1950; Kiviat 1993), beavers (Castor canadensis Kuhl), Norway rats (Rattus norvegicus Berkenhout), Eastern chipmunks (Tamias striatus Richardson), gray squirrels (Sciurus carolinensis Ord), and red squirrels (Tamiasciurus hudsonicus Bangs) (Hummel and Kiviat 2004). In one study, 58 intervertebrate species were associated with Trapa plants (Les 2018).

Materials published concerning the biology and ecology of Trapa natans and the features of its fruit lack data on the mechanical properties of the fruit. Examination of
Trapa natans fruit in terms of mechanical properties will help to better understand the mechanisms of functioning and the importance of the fruit's pericarp in the process of spreading this species and ensuring the best protection of its seeds against rodents. The fruit of the aquatic plant was used in the research, the pericarps of which are very succinct and may constitute a potential material for industrial use. The primary purpose of the research was to determine the amount of fruit crushing force during the drying process and the loss of water from both the pericarp and seeds. This work is innovative because the resistance of Trapa natans to crushing at various stages of drying is tested. So far, such studies have not been conducted on Trapa natans nuts.

Studying the physical and mechanical properties of agricultural products has been the subject of criticism and discussion for many years already and has attracted the attention of many researchers. The physical and mechanical properties of agriculture products are the most important parameters in the design of agricultural machinery sorting systems, transmissions, processing, and packaging systems (Ahangarnezhad et al 2019).

Research on the physical and mechanical properties of agricultural crops is related among others to Cassava harvesting machines (Atsyo et al. 2020); mechanization of the potato harvest (Ahangarnezhad et al. 2019); the possibility of breaking the seed shell of peanuts (Kurt and Arioglu 2018); the possibilities of red beet processing (Schäfer et al. 2020); designing equipment for transporting and storing peaches (Zohrabi et al 2013); transporting cherries (SharifiSangdeh and Aghkhani 2018); distinguishing varieties of lemons (Baradaran Motie et al. 2014); and collecting data of apples for the harvesting robot (Li et al. 2017).

\section{Materials and methods}

Trapa natans fruit collection was carried out in the third week of July 2018. It was collected from an Odra oxbow lake called Matunin, near Jelcz-Laskowice in Poland (N: $51^{\circ} 0^{\prime}$ $47^{\prime \prime}$; E: $\left.17^{\circ} 18^{\prime} 55^{\prime \prime}\right)$. The population in this reservoir is one of the largest in the region of Lower Silesia (SW Poland) and annually covers about 2 ha. The oxbow lake belongs to the typical eutrophic reservoir type with phytocoenoses of reed beds of the Phragmitetea class, communities of aquatic plants (Potametea class), and pleustonic (Lemnetea minoris class) plant communities (Kazuń 2005).

Due to the protection of Trapa natans in Poland, fruit collection was done after obtaining permission from the Regional Director for Environmental Protection in Wrocław (decision No. WPN.6400.22.2018.IL). Fruits were obtained directly from plants rooted at the bottom of the reservoir. Only ripe fruits were chosen, i.e. easily detached from the 
peduncle submerged in water. After harvesting, the fruits were placed in a sealed container (without air access) filled with water from the oxbow lake and delivered to the laboratory of the Department of Carpology at the University of Kazimierz Wielki in Bydgoszcz, where they were stored at $20{ }^{\circ} \mathrm{C}$. The fruits were first pulled out of the water and placed in cotton gauze bags. The bags were then hung on a boom in a fume hood where the fruit dried naturally at $20{ }^{\circ} \mathrm{C}$ and relative humidity of $30 \%$. Once a week, 5 fruits were selected from this collection for endurance tests. A total of 30 such trials were carried out using 30 fruits. The criteria for classifying ripe/unripe fruit was the size of the fruit. Morphological and anatomical observations of large and small fruit showed that the smaller the fruit, the less developed its pericarp, the larger the fruit, the thicker is the pericarp.

Nut crushing was carried out at the Department of Mechanics and Computer Methods of the University of Science and Technology in Bydgoszcz on a ZD40 device with an MGCPlus measuring amplifier, U2B force meter, and WA50 displacement meter. All measuring instruments have an accuracy class of $0.1 \%$. The schematic of the test stand for compressive loading is shown in Fig. 1. Fruit crushing was carried out along the longitudinal axis. The tests were carried out on five samples after each period of desiccation: immediately out of the water and after 1 to 5 weeks after removal from the water. After rejecting the most extreme values, the rest of the results were subjected to further analysis.

According to statistical criteria, three samples constitute a scarce population; therefore instead of a standard error of the mean, the confidence interval for a level of confidence of 0.95 was calculated.

The crushing force $(\mathrm{CF})$ is the maximum compressive force that occurs during each crushing test. The crushing work $(\mathrm{CW})$ was calculated numerically from the starting point of the test until the $\mathrm{CF}$ was reached, as given in the subsequent Eq. (1):

$C W=\int_{0}^{Z \max } F d z$

where $F$ is an instant applied compressive force and $z_{\max }$ is the deformation of the water caltrop measured in the direction of the force $F$ that occurs when $F$ reaches its maximum value $(\mathrm{CF})$.

In the literature, one can find attempts to calculate stresses in the nut's shell and its Young's modulus approximating the nut's pericarp by a regular sphere and applying the equations of shell theory. For example, according to Wang and Mai (1995), such a method was applied to macadamia nuts. However, in contrast to macadamia nuts, water caltrops have a very irregular pericarp, so it is challenging to estimate the stresses that occur in them during compressive loading. Nevertheless, a hardness parameter
Fig. 1 Schematic of the test stand for compressive loading: (1) ZD40 device, (2) MGCPlus measuring amplifier, (3) U2B force meter, (4) WA50 displacement meter, (5) computer, (6) clumps, (7) water caltrop

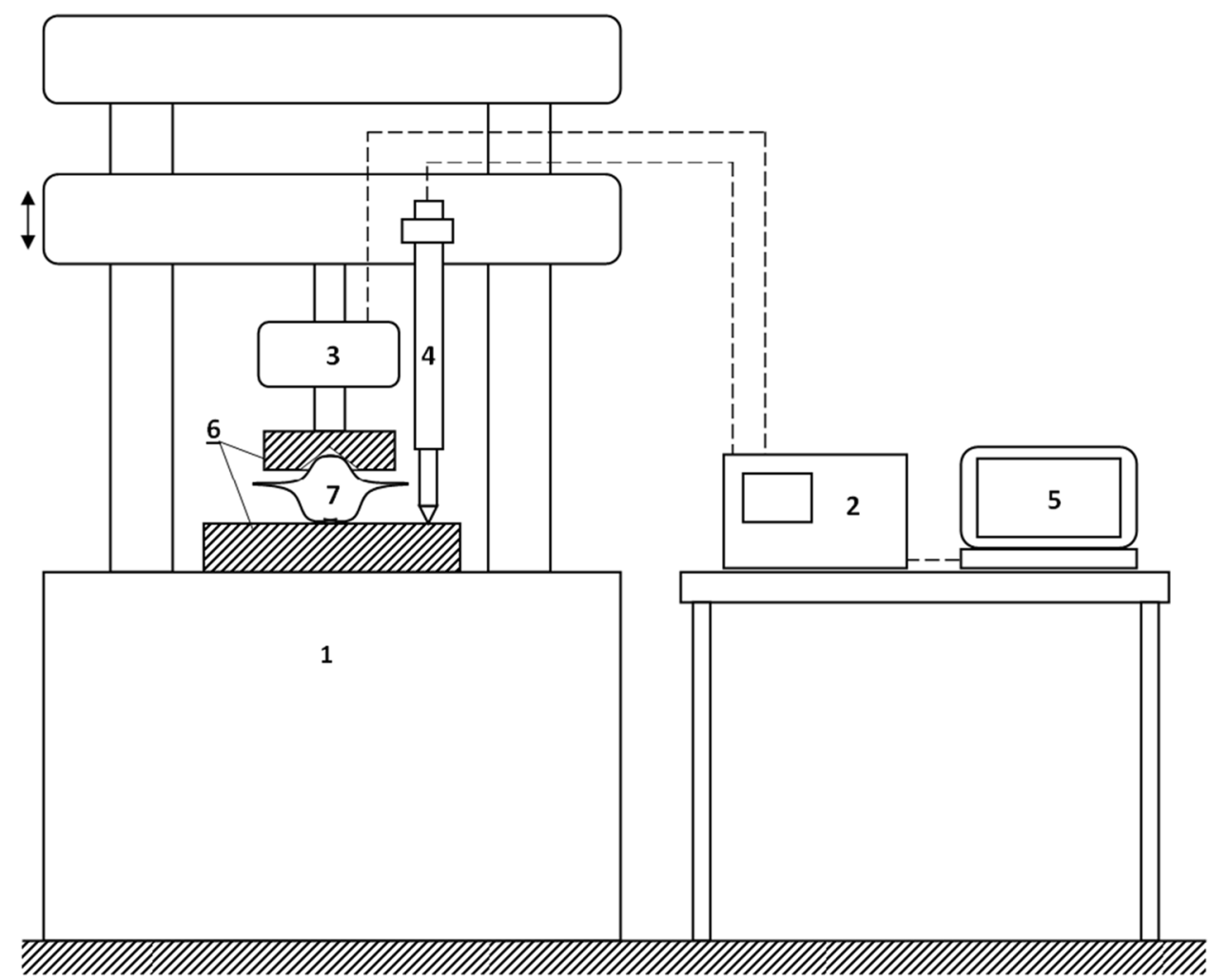


(HRD) was introduced to reflect the relationship between compressive loading $(\mathrm{N})$ and longitudinal strain $(\mathrm{mm} /$ $\mathrm{mm})$. The hardness parameter is defined by Eq. (2):

$H R D=\frac{\Delta F_{C}}{\Delta_{\varepsilon}}\left[\frac{N}{m m / m m}\right]$,

where $\Delta \varepsilon$ is longitudinal strain increment defined as a ratio of linear deformation increment to initial length (LZ) of the water caltrop, which relates to the respective compressive force increment $\Delta F_{C}$. Eventually, the introduced parameter $\operatorname{HRD}\left[\frac{N}{m m / m m}\right]$ has a similar meaning to elasticity modulus $\left[\frac{\mathrm{MPa}}{\mathrm{mm} / \mathrm{mm}}\right]$.

The fruit's pericarps were examined with a Hitachi scanning electron microscope at the Silesian University of Technology in Katowice. The outer and inner surfaces of the pericarp and a cross-section of the pericarp were observed.

\section{Results}

\section{Structure of the Trapa natans fruiting plant in SEM}

The cross-section of the Trapa natans fruit wall, $1327-1420 \mu \mathrm{m}$ thick, has no uniform structure. The examined fragment of the pericarp comes from the central part of the fruit. The outer part of the pericarp is more compact, $500 \mu \mathrm{m}$ thick with densely arranged fibres, while the

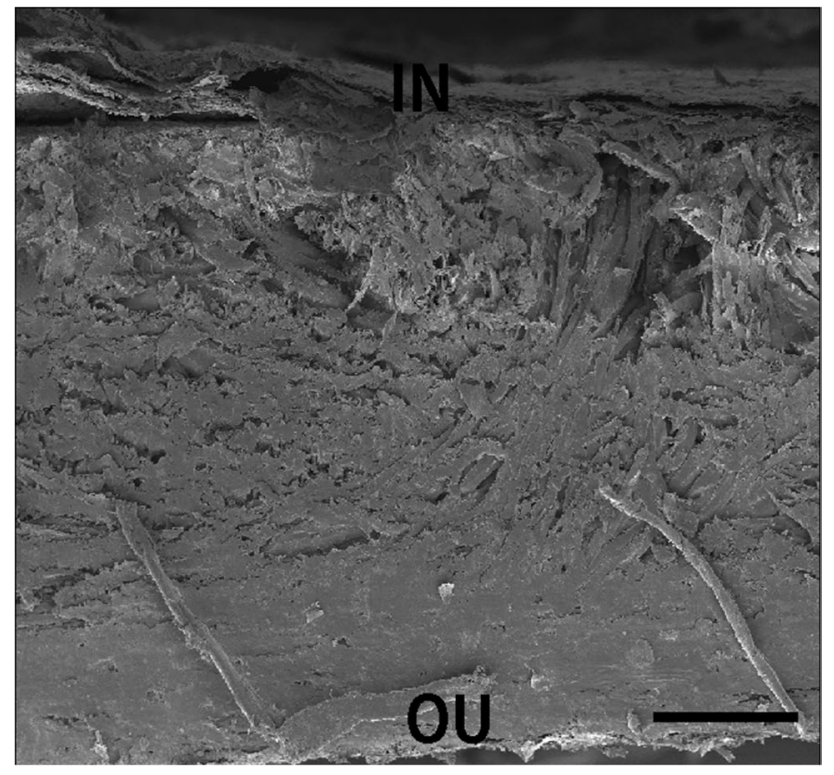

Fig. 2 Cross-section of the wall of the Trapa natans fruit in SEM. OU, outer surface; IN, internal surface. Bar, $300 \mu \mathrm{m}$

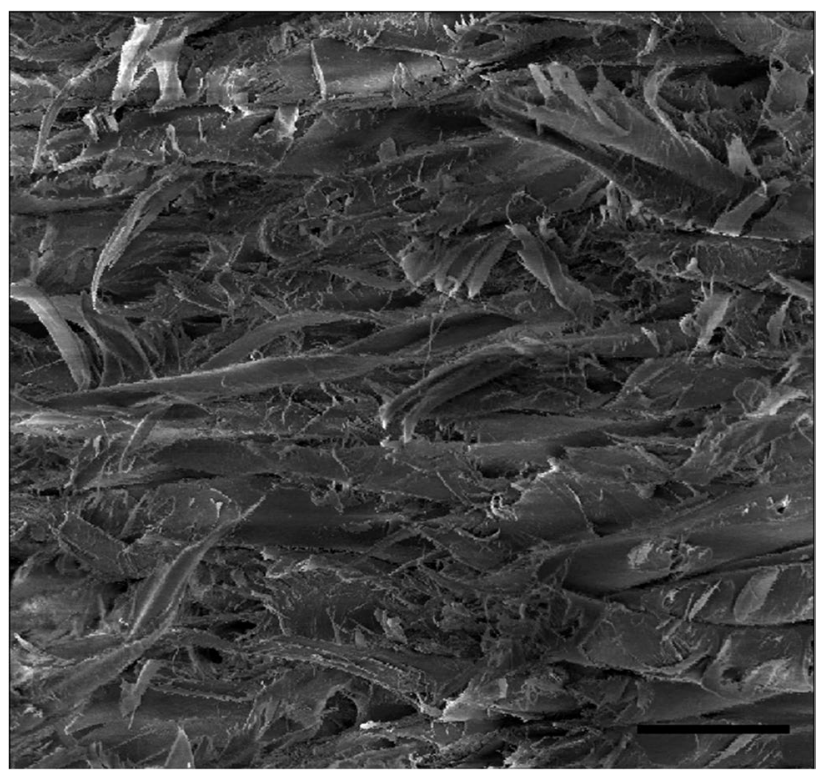

Fig. 3 Breakthrough wall of Trapa natans fruit. Bar, $60 \mu \mathrm{m}$

inner part of $900 \mu \mathrm{m}$ thick is less compact (Fig. 2). Breaking through the fruit wall shows the end of a wood fibre pericarp with a thickness of 23-28 $\mu \mathrm{m}$ (Fig. 3).

Using a scanning electron microscope, very densely arranged wood fibres form a spatial network. The fibres arranged in the inner layer of the pericarp are very regular and intertwine with each other to form a structure resembling a composite. Cavities are 55-214 $\mu \mathrm{m}$ in size and are arranged at different depths in the pericarp (Figs. 4-5). The

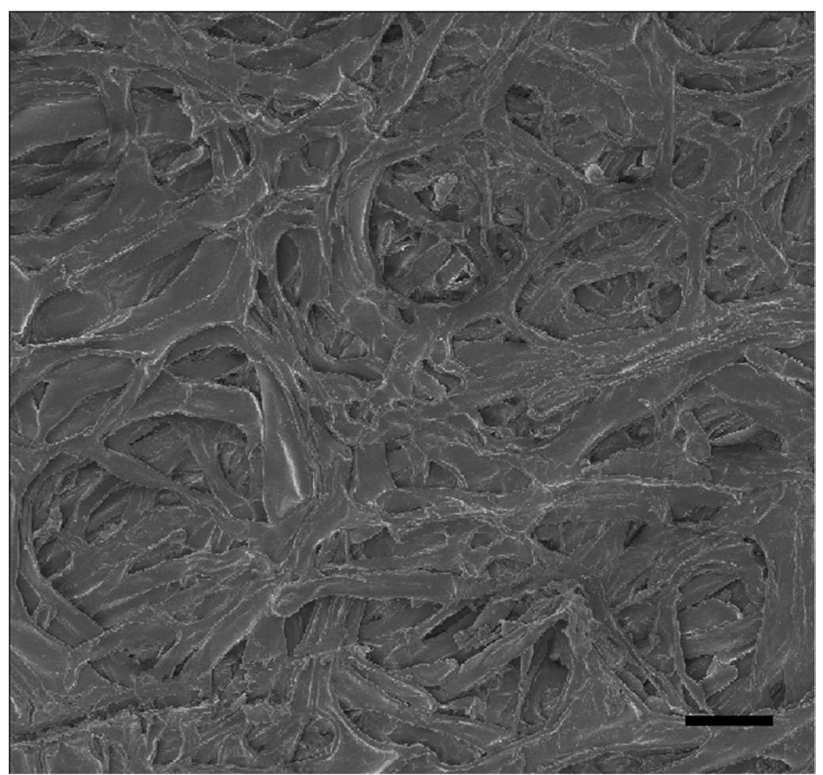

Fig. 4 Internal structure of the fruit wall of Trapa natans. Bar, $100 \mu \mathrm{m}$ 


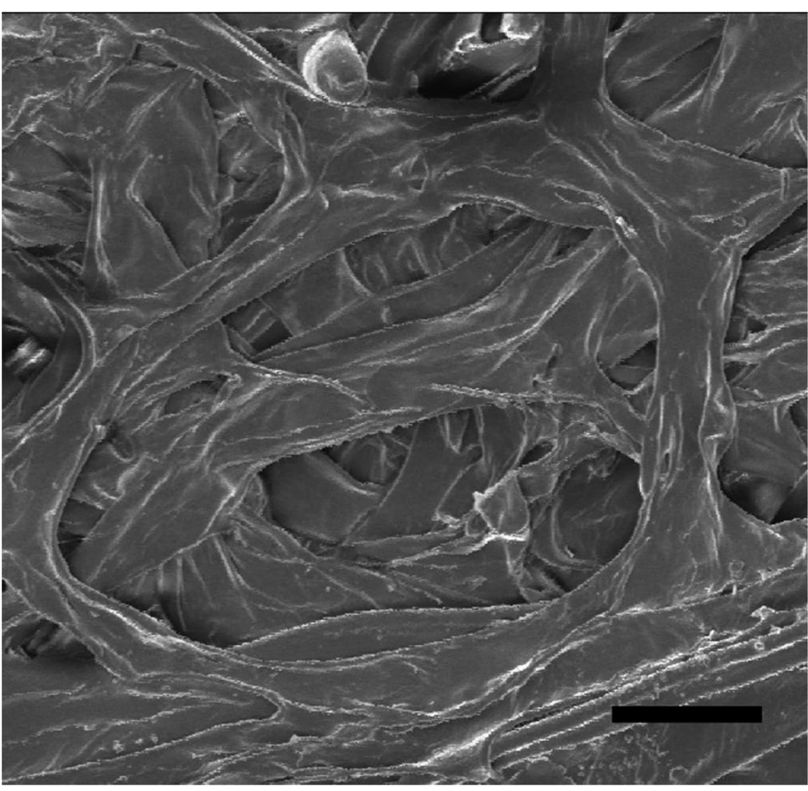

Fig. 5 Internal structure of the fruit wall of Trapa natans. Bar, $50 \mu \mathrm{m}$

pericarp of Trapa natans has such a compact structure that it is difficult to cut it with a scalpel to obtain a cross-section.

\section{Pericarp strength tests}

The force was applied along axis $Z$ during the compression tests, as seen in Fig. 6. An example graph in Fig. 7 presents the course of compressive force as a function of deformation along axis $Z$ for three samples after 2 weeks of desiccation. These are sample numbers 7-9 in Table 1. The measured values of masses, crushing forces, and crushing works are also given in Table 1. Figure 8 shows a visualization of the

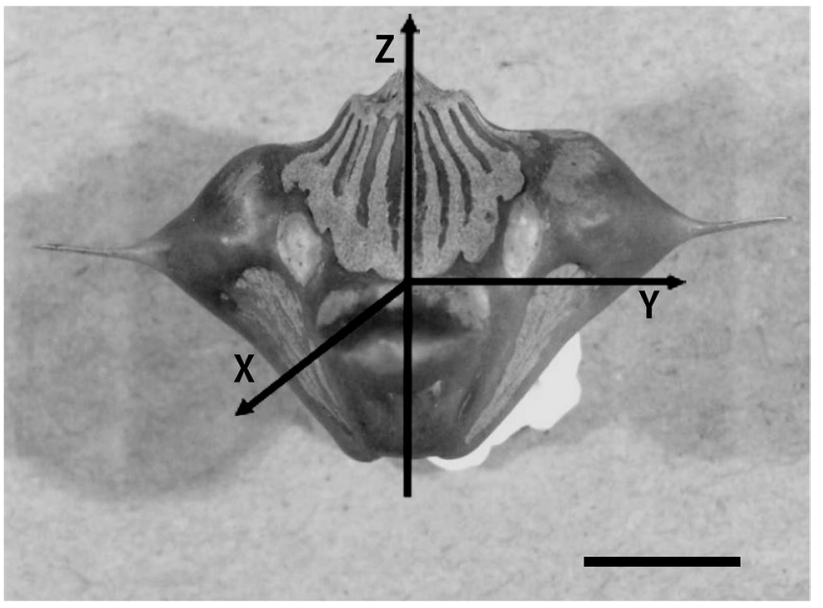

Fig. 6 Example water caltrop and assumed axes of Cartesian coordinate system with a scale given in centimetres. Bar, $1 \mathrm{~cm}$

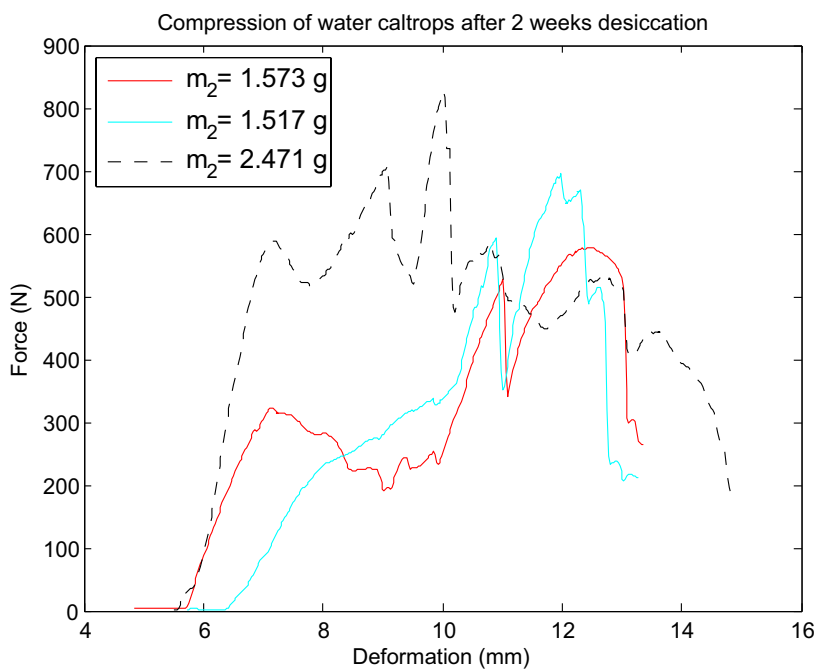

Fig. 7 The course of compressive force as a function of deformation for three samples of given masses after 2 weeks desiccation

measured values of $\mathrm{CF}$ after each period of desiccation, their mean values, and the limits of confidence intervals.

The analysis of results given in Table 1 and Fig. 8 reveals that after 2 weeks of desiccation, the structure of the water caltrop is the most resistant and the greatest forces are needed to crush the sample. The maximum crushing force registered during tests was $828.7 \mathrm{~N}$ and the largest calculated crushing work was $2185.5 \mathrm{~mJ}$ for the same fruit number 9 in Table 1. The course of the crushing test for this sample is visualized by the dashed line in Fig. 7. Nevertheless, the measurements of the CF after 2 weeks of desiccation have the widest confidence intervals because of the significant influence of internal structure on the mechanical properties of the water caltrop. The structure is highly anisotropic, as seen in Fig. 3.

The hardness parameter (HRD) was defined as a ratio of the compressive force increment to the longitudinal strain increment. These increments were measured in the first, steepest linear growth of the compressive force as a function of deformation. For example, in Fig. 7, the hardness of the nut with a mass $m_{2}=1.517 \mathrm{~g}$ was calculated in a range of displacement from 10.28 to $10.75 \mathrm{~mm}$. Irregularities in the initial stage of each line in Fig. 7 reflect possible slight movements of the sample in compressing clumps.

Table 1 presents the geometrical and mechanical properties of water caltrops used for compressive testing. Two other parameters were calculated to consider the influence of mass and size on the caltrop's compression strength. These were the specific crushing energy (SCE) and the unit crushing force (UCF). SCE is defined as a ratio of crushing work to water caltrop's mass, and UCF is a ratio of crushing force to its thickness (TWS) measured along the $X$ axis (Fig. 6) without spikes. Parameters LZ and TWS 
Table 1 Mechanical properties of water caltrops after each week of desiccation: LZ, initial length of water caltrop; TWS, thickness measured without spikes; $C F$, crushing force; $H R D$, hardness parameter expressing the relationship between compressive loading and longitudinal strain

\begin{tabular}{|c|c|c|c|c|c|c|c|c|c|c|}
\hline \multirow[t]{3}{*}{ Spec no. } & \multicolumn{10}{|c|}{ Mass after number of weeks of desiccation ( $\mathrm{g}$ ) } \\
\hline & $m_{0}$ & $m_{1}$ & $m_{2}$ & $m_{3}$ & $m_{4}$ & $m_{5}$ & $\mathrm{LZ}(\mathrm{mm})$ & TWS (mm) & $\mathrm{CF}(\mathrm{N})$ & $\operatorname{HRD}(\mathrm{N})$ \\
\hline & out of water & 1 week & 2 weeks & 3 weeks & 4 weeks & 5 weeks & & & & \\
\hline 1 & 3.508 & & & & & & 20.16 & 10.10 & 209.7 & 6171 \\
\hline 2 & 3.803 & & & & & & 20.13 & 10.30 & 281.9 & 2545 \\
\hline 3 & 5.647 & & & & & & 20.46 & 10.36 & 227.9 & 4365 \\
\hline 4 & 3.916 & 2.426 & & & & & 20.16 & 10.25 & 372.0 & 3071 \\
\hline 5 & 3.516 & 2.395 & & & & & 20.25 & 10.32 & 385.9 & 6874 \\
\hline 6 & 4.24 & 2.322 & & & & & 20.41 & 10.15 & 446.1 & 8017 \\
\hline 7 & 3.413 & 2.546 & 1.573 & & & & 20.22 & 10.22 & 578.7 & 4995 \\
\hline 8 & 3.016 & 2.379 & 1.517 & & & & 20.08 & 10.33 & 698.8 & 7293 \\
\hline 9 & 4.679 & 3.381 & 2.471 & & & & 20.22 & 10.30 & 828.7 & 10.443 \\
\hline 10 & 3.676 & 2.246 & 1.735 & 1.333 & & & 20.14 & 10.22 & 317.6 & 4220 \\
\hline 11 & 4.081 & 1.641 & 1.494 & 0.984 & & & 20.20 & 10.35 & 311.7 & 4474 \\
\hline 12 & 4.258 & 3.041 & 2.562 & 2.479 & & & 20.35 & 10.31 & 347.6 & 4395 \\
\hline 13 & 3.009 & 1.162 & 0.981 & 0.964 & 0.940 & & 20.93 & 10.11 & 283.4 & 3937 \\
\hline 14 & 3.887 & 2.602 & 1.237 & 1.049 & 0.978 & & 20.11 & 10.33 & 192.6 & 2236 \\
\hline 15 & 3.352 & 2.106 & 1.168 & 1.087 & 1.077 & & 20.94 & 10.25 & 237.8 & 1771 \\
\hline 16 & 3.111 & 2.283 & 1.668 & 1.662 & 1.624 & 1.544 & 20.10 & 10.41 & 302.7 & 7120 \\
\hline 17 & 4.407 & 3.232 & 2.398 & 2.25 & 2.213 & 2.031 & 20.27 & 10.30 & 517.8 & 7754 \\
\hline 18 & 3.322 & 2.089 & 1.814 & 1.697 & 1.523 & 1.248 & 20.15 & 10.20 & 329.7 & 4492 \\
\hline
\end{tabular}

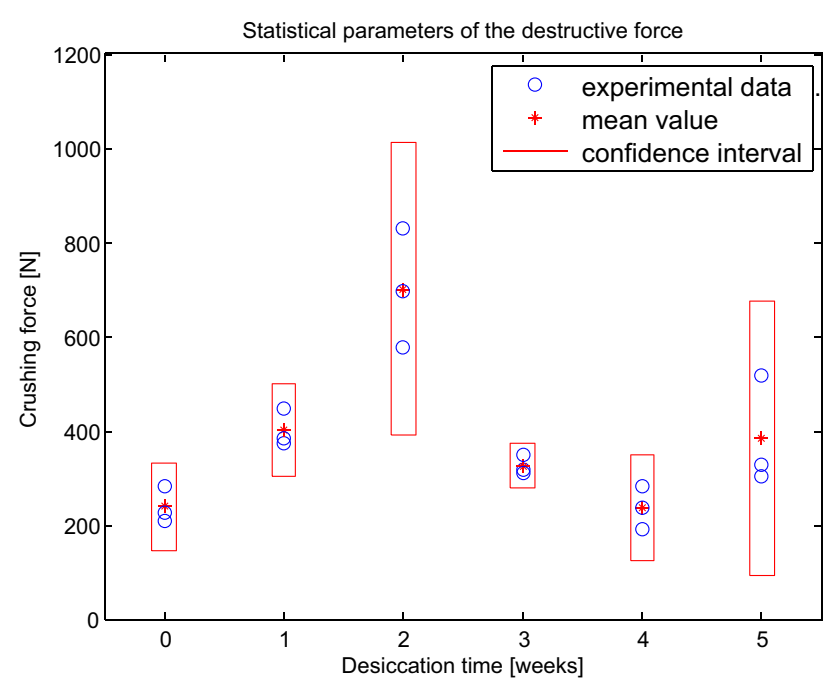

Fig. 8 Visualization of measurements and statistical parameters of crushing force after each period of desiccation (in weeks)

are nut's dimensions that can be precisely measured. Wide confidence intervals of all strength parameters, i.e. $\mathrm{CF}$, HRD, SCE, and UCF, indicate that the pericarp's irregularity and anisotropic shell structure predominantly influence the mechanical properties of water caltrops. Nevertheless, the analysis of results in Table 1 and Table 2 concludes that after 2 weeks of desiccation, all the nut's strength parameters tend to their maximum values.

The measured masses of caltrops were also applied to model the desiccation process by an exponential curve given by function (3):

$m=B+\left(m_{0}-B\right) e^{-t}$,

where $B$ is the constant calculated by the least square method.

A graph comparing the measured values of caltrop mass after each week of desiccation with the values calculated by function (3) is presented in Fig. 9.

\section{Discussion}

Trapa natans nuts reduced their weight during drying in laboratory conditions. However, this process did not increase the mechanical resistance of the nuts. In the natural environment, Trapa natans fruits are found in water, on the outskirts of water reservoirs and in bottom sediments, e.g. fish ponds, where they retain their germination potential for many years. However, the subject of research was not germination, depending on many factors, but the persistence of the pericarp, i.e. its resistance to crushing force during the drying process. Lower mechanical resistance of the pericarp 
Table 2 The mean values of physical and calculated compression parameters and their confidence intervals: $L Z$, initial length of water caltrop; $T W S$, thickness measured without spikes; $C F$, crushing force;
$C W$, crushing work; $H R D$, hardness parameter expressing the relationship between compressive loading and longitudinal strain; SCE, specific crushing energy; $U C F$, unit crushing force

\begin{tabular}{lllllcc}
\hline Desiccation time & Right out of water & 1 week & 2 weeks & 3 weeks & 4 weeks \\
\hline Mass $(\mathrm{g})$ & $4.319 \pm 2.880$ & $2.381 \pm 0.133$ & $1.875 \pm 1.33$ & $1.600 \pm 1.943$ & $0.998 \pm 0.176$ & $1.608 \pm 0.982$ \\
LZ $(\mathrm{mm})$ & $20.25 \pm 0.45$ & $20.27 \pm 0.31$ & $20.17 \pm 0.20$ & $20.23 \pm 0.27$ & $20.66 \pm 1.18$ & $20.17 \pm 0.22$ \\
TWS $(\mathrm{mm})$ & $10.28 \pm 0.21$ & $10.24 \pm 0.21$ & $10.28 \pm 0.14$ & $10.29 \pm 0.17$ & $10.23 \pm 0.28$ & $10.30 \pm 0.26$ \\
CF $(\mathrm{N})$ & $240 \pm 93$ & $401 \pm 98$ & $701 \pm 311$ & $326 \pm 48$ & $238 \pm 113$ & $383 \pm 291$ \\
CW $(\mathrm{mJ})$ & $276 \pm 406$ & $1058 \pm 699$ & $2034 \pm 550$ & $565 \pm 839$ & $375 \pm 119$ & $428 \pm 197$ \\
HRD $(\mathrm{N})$ & $4360 \pm 4505$ & $5988 \pm 6432$ & $7577 \pm 6795$ & $4363 \pm 323$ & $2648 \pm 2833$ & $6455 \pm 4296$ \\
SCE $(\mathrm{mJ} / \mathrm{g})$ & $68 \pm 116$ & $444 \pm 275$ & $1138 \pm 593$ & $461 \pm 1095$ & $375 \pm 82$ & $270 \pm 76$ \\
UCF $(\mathrm{N} / \mathrm{mm})$ & $23.3 \pm 3.58$ & $39.2 \pm 10.3$ & $68.2 \pm 29.6$ & $31.6 \pm 4.64$ & $23.3 \pm 11.7$ & $37.2 \pm 28.4$ \\
\hline
\end{tabular}

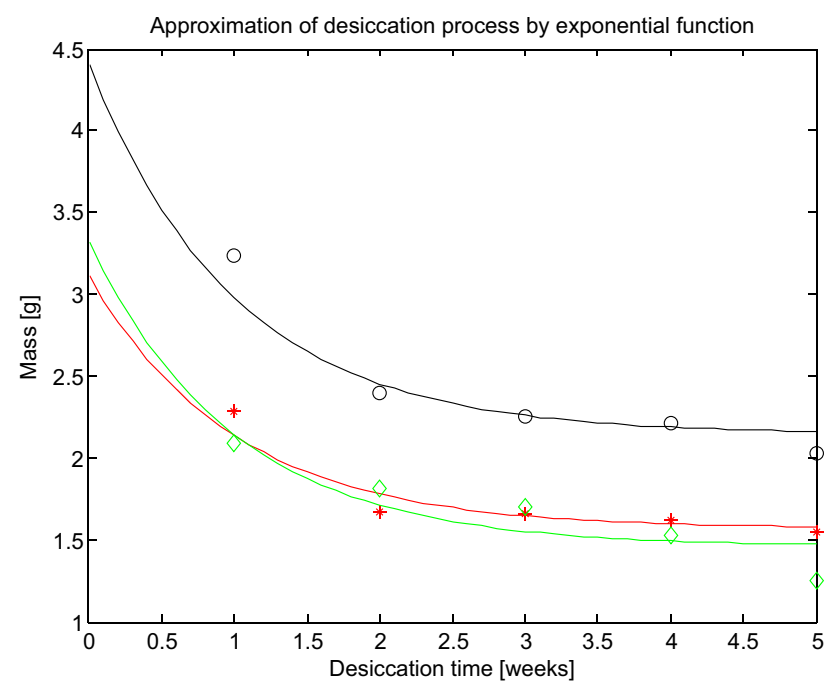

Fig. 9 Comparison of measured masses during the desiccation process and their approximation by the exponential function (3)

of Trapa natans occurs in ripening nuts that have not yet reached the final dimensions for the species.

This study showed that a mature pericarp has the highest mechanical resistance when its hydration is still relatively high (second week of drying). Therefore, as long as the Trapa natans fruits are moist, their resistance to destruction during biting by animals is the highest. This feature indicates Trapa's significant evolutionary adaptation to protect its seeds in aquatic environments.

If we look at the structure of the Trapa natans nut pericarp, it becomes clear that it supports nut crack resistance due to its compact composite structure. It is worth adding that nuts are biological objects that are characterized by variability. One symptom of this variation is the different degrees of pericarp thickness in different locations of the pericarp. The fruit's complete resistance to cracking depends on many fruit features and external factors related to the species' environment, such as water quality and temperature.
Among the fruit features affecting the fruit's total mechanical resistance are the size and shape of the fruit, the degree of fruit spike formation, pericarp thickness, and the degree of tissue hydration. It would also be interesting to examine the resistance of the pericarp to crushing at various temperatures. This characteristic of pericarp fibres may be of great importance in industrial use and requires further research.

Natural fibres are usually believed to have several benefits compared to synthetic fibres, such as availability, low cost, low density, acceptable modulus-weight ratio, high acoustic damping, low manufacturing energy consumption, low carbon footprint, and biodegradability (Mohanty et al. 2005). Plant fibres can also be regarded as fillers to replace the more expensive polymers and improve the green credentials of the final composite parts (Fortea-Verdejo et al. 2017). For example, fibres from fruit produced by species of the genera Borassus and Tamarind have been successfully used in composites used in construction engineering (Nayak et al. 2019).

Among the fibres derived from Areca catech $u$, it is worth paying attention to the construction of the betel nut and glass fibre composite. Palm fruit fibres can be successfully used as reinforcing fibres in polyethylene composites in the automotive industry and food packaging (Merajul Haque and Hasan 2016). Natural fibre composites are considered to have potential use as reinforcing material in polymer matrix composites because of their good strength, stiffness, low cost, environmental friendliness, and biodegradability (Srinivasa and Bharath 2011). Natural fibres are playing an increasing role as reinforcement in polymer composites (Bensadoun et al. 2017). The need for natural fibre-reinforced composites is increasing at a very fast rate because of their ecofriendly production, decomposition, high specific strength, abundance, and good physical and mechanical properties (Latif et al. 2019). Palm fruit fibres and sawdust are used as building materials (Sosu et al. 2011). Palm fibres are also used in water filtration filters (Idris et al. 2017), for the production of bio-oil (Onifade et al. 2017), frictional material (Achebe et al. 2019), and in biomedicine (Namvar et al. 2014). Up 
to now are no reports regarding the mechanical properties of Trapa natans nuts. Existing reports relate to the physical and mechanical properties of terrestrial nuts that are used industrially. In Juglans regia (Ercisli et al. 2011), features such as length, width, thickness, mass, geometric mean diameter, deformation at cracking, and cracking force have been examined. The microstructure and mechanical properties of Macadamia nutshells (Wang and Mai 1995) have been examined and heat treated. Macadamia nutshells are similar to wood, except that they may have different aspect ratios. The strength of the Macadamia nutshell is naturally a compromise between attaining high strength and achieving isotropy as required by the need to provide all-round protection to the seed (Wang and Mai 1995). In the case of Trapa natans, the seed does not adhere completely to the pericarp, as is the case with Macadamia nuts, which affects the overall mechanical resistance of the nut. In addition, the seed of the aquatic plant is dehydrated and shrinks in the drying process, which causes the seed to stand slightly away from the pericarp wall in the dried fruit.

Comparing compression parameters of water caltrop with the mechanical properties of other types of nuts available in the scientific literature leads to the following conclusion: water caltrops need a greater compressive force and work to be crushed than walnuts tested (Ercisli et al. 2011). Nevertheless, the water caltrop's compressive strength is lower than that of macadamia nuts (Wang and Mai 1995).

The mechanical properties of pistachios increased with decreasing moisture. Deformation and deformation ratio, which decreased with decreasing moisture content, were also studied (Razavi and Edalatian 2012). In the case of Trapa natans nuts, they had the greatest mechanical resistance to compression during the 2 nd week of testing, i.e. when they were not completely dried. The force in newtons needed to crush the Trapa natans nut was $25 \times$ greater than the maximum force used to crush the pistachio nut.

With the recent development of biomimetics (Vincent 2012) as a method of incorporating the characteristics of biological materials and microstructures into engineering design, more and more attention is being paid to the direction of biological materials research. We hope that initial research into the structure and mechanics of the Trapa natans pericarp will stimulate scientists' interest in further studies on the properties of the fibre and its use for industrial purposes.

Research has shown that the fruit is the most durable in the second week of drying. This is of great practical importance when looking for biodegradable material with high crush resistance. Further testing of Trapa natans pericarps should be taken from the nuts in the 2nd week of drying. An important evolutionary significance of our research is determining the maximum hardness of fruits that are still partially hydrated and as resistant to animal chewing as possible. Trapa natans fruits protect the seeds from eating to the maximum extent as long as they are moist, so as long as they retain their ability to germinate.

\section{Conclusions}

The study showed the effect of water content on water caltrop fruit resistance to crushing and resistance to fruit destruction by animals. Different degrees of hydration significantly impact the amount of force that causes the fruit to crack. Greater force is needed for crushing hydrated fruit than for crushing dry fruit. As the water content in the pericarp increases, the force needed to break the fruit increases. Thanks to the high strength of the pericarp, the seeds are well protected against mechanical damage, including cracking, and complete drying, which, among other things, allows them to be transported through water or by animals over long distances. The mechanical properties of Trapa natans fruit and pericarp building fibres described in the article indicate their potential for application in the industry. Potentially, the plant material of Trapa natans pericarps, due to its high mechanical resistance, can be used in industrial processing, e.g. the production of seals for amphibious vehicles, hovercraft, inflatable boats, and rafts for recreational purposes or small reinforcing elements in aquarium systems or in the production of fishing equipment.

Open Access This article is licensed under a Creative Commons Attribution 4.0 International License, which permits use, sharing, adaptation, distribution and reproduction in any medium or format, as long as you give appropriate credit to the original author(s) and the source, provide a link to the Creative Commons licence, and indicate if changes were made. The images or other third party material in this article are included in the article's Creative Commons licence, unless indicated otherwise in a credit line to the material. If material is not included in the article's Creative Commons licence and your intended use is not permitted by statutory regulation or exceeds the permitted use, you will need to obtain permission directly from the copyright holder. To view a copy of this licence, visit http://creativecommons.org/licenses/by/4.0/.

\section{References}

Achebe C, Obika E, Chukwuneke J, Ani O (2019) Optimisation of hybridised cane wood-palm fruit fibre frictional material. Proceedings of the IMechE 233:2490-2497. https://doi.org/10.1177/ 1464420719863445

Ahangarnezhad N, Najafi G, Jahanbakhshi A (2019) Determination of the physical and mechanical properties of a potato (the Agria variety) in order to mechanise the harvesting and post-harvesting operations. Res Agric Eng 65:33-39. https://doi.org/10.17221/ 122/2017-RAE

Atsyo SY, Korkmaz C, Ozluoymak OB, Guzel E (2020) A review of physical and mechanical properties of cassava related to 
harvesting machines. Int J Sci Technol 6:102-118. https://doi. org/10.20319/mijst.2020.62.102118

BaradaranMotie J, MiraeiAshtiani SH, Abbaspour-Fard M, Emadi B (2014) Modeling physical properties of lemon fruits for separation and classification. Int Food Res J 21:1901-1909

Bensadoun F, Verpoest I, Baets J et al (2017) Impregnated fibre bundle test for natural fibres used in composites. J Reinf Plast Compos 36:942-957. https://doi.org/10.1177/0731684417695461

Bharthi V, Kavya B, Shantha TR et al (2015) Pharmacognostical evaluation and phytochemical studies on Ayurvedic nutritional fruits of Trapa natans L. Int J Herb Med 3:13-19

Chaudhary J, Jain A, Bhatiwal S (2012) Trapa natans (water chestnut): an overview. Int Res J Pharm 3:31-33

Ercisli S, Kara M, Ozturk I et al (2011) Comparison of some physicomechanical nut and kernel properties of two walnut (Juglans regia L.) cultivars. Not Bot Horti Agrobot 39:227-231

Fortea-Verdejo M, Bumbaris E, Burgstaller C et al (2017) Plant fibrereinforced polymers: where do we stand in terms of tensile properties? Int Mater Rev 62:441-464. https://doi.org/10.1080/09506 608.2016.1271089

Gani A, Haq SS, Masoodi FA et al (2010) Physico-chemical, morphological and pasting properties of starches extracted from water chestnuts (Trapa natans) from three Lakes of Kashmir, India. Braz Arch Biol Technol 53:731-740. https://doi.org/10.1590/S151689132010000300030

Hultén E, Fries M (1986) Atlas of north European plants north of the Tropic of Cancer. Lubrecht \& Cramer Ltd, Königstein, Federal Republic of Germany

Hummel M, Kiviat E (2004) Review of world literature on water chestnut with implications for management in North America. J Aquat Plant Manag 42:17-28

Idris J, Osman SF, Gaius E, Christian C (2017) A comparison study of water filtering materials made from extracted palm fruit fibre and palm kernel shell. Environ Eng Manag J 16:2665-2672. https:// doi.org/10.30638/eemj.2017.276

Javed S, Yousaf Z, Rashid M et al (2016) Pericarp of Trapa natans var. bispinosa (Roxb.) Makino as an organic herbicide. Int J Adv Agric Res 4:94-104

Kazuń A (2005) Zbiorowiska roślinne projektowanego rezerwatu "Matunin" koło Jelcza w powiecie oławskim. Acta Bot Siles 2:25-77

Kiviat E (1993) Under the spreading water-chestnut. News from Hudsonia 9:1-6

Kurt C, Arioglu H (2018) Physical and mechanical properties of some peanut varieties grown in Mediterranean environment. Cercet Agron Mold 51:27-34. https://doi.org/10.2478/cerce-2018-0013

Latif R, Wakeel S, Zaman Khan N et al (2019) Surface treatments of plant fibers and their effects on mechanical properties of fiberreinforced composites: a review. J Reinf Plast Compos 38:15-30. https://doi.org/10.1177/0731684418802022

Les DH (2018) Aquatic dicotyledons of North America: ecology, life history, and systematics. CRC Press, Taylor \& Francis Group, Boca Raton

Li Y, Du X, Wang J, Lei C (2017) Study on mechanical properties of apple picking damage. Adv Eng Res 120:1666-1670. https://doi. org/10.2991/ifeesm-17.2018.304

Merajul Haque M, Hasan M (2016) Mechanical properties of betel nut and glass fibre reinforced hybrid polyethylene composites. Int J Automot Mech Eng 13:3763-3772. https://doi.org/10.15282/ ijame.13.3.2016.18.0308

Mohanty AK, Misra M, Drzal LT (eds) (2005) Natural fibers, biopolymers, and biocomposites, 1st edn. CRC Press Taylor \& Francis, Boca Raton

Muenscher WC (1937) Water chestnut. In: A biological survey of the lower Hudson watershed. Albany, pp 234-243, 246
Namvar N, Namvar M, Md Tahir MT et al (2014) Potential use of plant fibres and their composites for biomedical applications. BioResources 9:5688-5706

Nayak SY, ShenoyHeckadka S, Thomas LG (2019) Evaluation of physico-mechanical characteristics of cashew nut shell liquid-epoxy composites with Borassus and Tamarind fruit fibres as reinforcements. J Nat Fibers 16:328-341. https://doi.org/10.1080/15440 478.2017.1423254

Onifade TB, Wandiga SO, Bello IA et al (2017) Conversion of lignocellulose from palm (Elaeis guineensis) fruit fibre and physic (Jatropha curcas) nut shell into bio-oil. Afr J Biotechnol 16:21672180. https://doi.org/10.5897/AJB2017.16004

Petrović D, Jančić D, Furdek M et al (2016) Aquatic plant Trapa natans L. as bioindicator of trace metal contamination in a freshwater lake (Skadar Lake, Montenegro). Acta Bot Croat 75:236-243. https://doi.org/10.1515/botcro-2016-0031

Piórecki J (1980) Kotewka-orzech wodny Trapa natans L. w Polsce. Rozmieszczenie, tempo zanikania stanowisk, użytkowanie i ochrona, biologia, ekologia i hodowla w warunkach półnaturalnych, badania eksperymentalne. Towarzystwo Przyjaciół Nauk w Przemyślu, Przemyśl.

Piórecki J (2014) Trapa natans L. Kotewka orzech wodny. In: Kaźmierczakowa R, Zarzycki K, Mirek Z (eds) Polska czerwona księga roślin. Paprotniki i rośliny kwiatowe, III. Polska Akademia Nauk Instytut Ochrony Przyrody, Kraków, pp 343-345.

Razavi SMA, Edalatian MR (2012) Effect of moisture contents and compression axes on physical and mechanical properties of pistachio kernel. Int J Food Prop 15:507-517. https://doi.org/10.1080/ 10942912.2010.492541

Schäfer J, Hale J, Hoffmann CM, Bunzel M (2020) Mechanical properties and compositional characteristics of beet (Beta vulgaris L.) varieties and their response to nitrogen application. Eur Food Res Technol 246:2135-2146. https://doi.org/10.1007/ s00217-020-03562-4

Shalabh B, Akash J, Jasmine C (2012) Trapa natans (Water chestnut): an overview [2012]. Int Res J Pharm 3:31-33

Sharifi-Sangdeh S, Aghkhani MH (2018) Investigation of the mechanical properties of cherry fruit (Prunus Cerasus L.) in order to achieve optimum height of fruit storage box. ARTOAJ 16. https:// doi.org/10.19080/ARTOAJ.2018.16.555996

Singh GD, Singh S, Jindal N et al (2010) Physico-chemical characteristics and sensory quality of Singhara (Trapa natans L.): an Indian water chestnut under commercial and industrial storage conditions. Afr J Food Sci 4:693-702

Sosu EK, Hasford F, Dadson ABC (2011) Study of mechanical properties of composite materials made from palm fruit fibre and sawdust. Res J Appl Sci Eng Technol 3:1441-1444

Srinivasa CV, Bharath KN (2011) Impact and hardness properties of areca fiber - epoxy reinforced composites. J Mater Environ Sci 2:351-356

Stevens PF (2001) Angiosperm Phylogeny Website. Version 14, July 2017 [continuously updated since]

Vincent J. (2012) Structural Biomaterials. 3rd ed. Princeton University Press, Princeton. https://www.perlego.com/book/735538/struc tural-biomaterials-pdf

Wang C-H, Mai Y-W (1995) Deformation and fracture of macadamia nuts: part 2: microstructure and fracture mechanics analysis of nutshell. Int J Fract 69:67-85. https://doi.org/10.1007/BF000 32189

Winne WT (1950) Water chestnut: a foreign menace. Bulletin to the Schools 36:230-234

Zając M, Zając A (2009) Element geograficzne rodzimej flory Polski. The Geographical Elements of Native Flora of Poland. Nakładem Pracowni Chorologii Komputerowej Instytutu Botaniki Uniwersytetu Jagiellońskiego, Kraków 
Zohrabi S, Seiiedlou S, Alipasandi A (2013) Study some physical and mechanical properties of three cultivars of peach in maturation stages. World Sci J 4:108-117

Publisher's Note Springer Nature remains neutral with regard to jurisdictional claims in published maps and institutional affiliations. 